\title{
Genotype by environment interaction and teak (Tectona grandis L.) selection in Costa Rica.
}

\author{
O. Murillo ${ }^{1 *}$, M.D.V. de Resende ${ }^{2}$, Y. Badilla' ${ }^{1}$ J.P. Gamboa ${ }^{1}$
}

\author{
${ }^{1}$ Instituto Tecnológico de Costa Rica. School of Forest Engineering. Cartago, Costa Rica \\ 2 Empresa Brasileira de Pesquisa Agropecuaria - Embrapa Florestas, Universidad Federal de Viçosa, M.G., Brasil \\ * Corresponding author: O. Murillo, Email: olmuga@yahoo.es
}

\begin{abstract}
A teak progeny trial was established with four replicates at different sites along the northern Pacific region of Costa Rica. The trials followed a randomized block design, with 28 open pollinated families and 36 seedlings per family per site. Data from 7 years-old trees was analyzed both for each test location separately and for all locations combined. High individual heritability was found for diameter, which translates to higher breeding potential. The all locations combined analysis showed high genetic variation, with individual heritabilities reaching up to $22 \%$. Genotype by Environment (GxE) interactions explained only $2.5 \%$ of total phenotypic variation. The genetic correlation ( $\mathrm{rg}$ ) among all four sites was 0.69 . Hence, it is concluded that GxE interactions are not problematic for breeding purposes since they are not complex in nature. This teak breeding population showed strong genetic stability and performed well in most environments in the study area. The Hojancha location showed high genetic correlation with all other sites; therefore, it should be chosen for future testing and selection of elite genotypes. Selection of the 20 best individuals, allowing for up to two individuals per family, would result in a $1.78 \mathrm{~cm}(11 \%)$ gain in diameter. Furthermore, based on this selection the inbreeding coefficient $(F)$ in the offspring would only reach $2.9 \%$, while the expected effective population size ( $\mathrm{Ne}$ ) would be16.97 individuals. This selection scheme could reduce rotation age by almost two years, since the diameter goal of $40 \mathrm{~cm}$ would be reached earlier than the usual 20 years cycle. The results suggest that the progeny trial can be maintained as a single breeding population, suitable for planting in any site along the Northern Pacific region of Costa Rica.
\end{abstract}

Keywords: : GXE interactions, tree improvement, tropical forestry, $B L U P / R E M L$, progeny test

\section{Introduction}

Teak has become one of the most planted tree species in the tropics due to its high wood prices in international markets. The species was introduced to most Latin-American countries through Trinidad and Tobago around 1913 (Keogh 1979, Schnell e Schuhli and Paludzyszyn 2010, Murillo et al. 2013). By the end of the 1970's an estimate 14000 ha were planted in the region (Keogh 1979). However, it was in the late 1980's that the planting rate increased significantly in response to a high demand and prices in the Asian markets (Pandey and Brown 2000, Moya, Solera and Guerrero 2013). In Latin America, teak breeding programs first started in Trinidad and Tobago supported by British scientists (Chalmers 1962). Numerous teak provenance trials were established in the region during the 1970's and 1980's, mostly through international cooperation with DANIDA/OXFORD (Boshier and Mesén 1987, Schnell e Schuhli and Paludzyszyn 2010). However, productivity was highly variable.

By the end of 2001, an international tree-breeding cooperative was created in Costa Rica, named GENFORES and based on clonal forestry (Gutiérrez et al. 2003, Murillo and Badilla 2004). Since its creation, over 400 teak plus trees have been selected, cloned, and field tested by GENFORES members and collaborators. Field testing is done under different ecological conditions and in several countries of the region (Vallejos et al. 2010, Espitia, Murillo and Castillo 2011, Murillo et al. 2013, Correa et al. 2013, Badilla, Xavier and Murillo 2016). In those trials, a moderate to strong genetic control with large genetic variation has been reported for diameter, commercial height, and commercial volume, i.e. narrow sense family heritabilities $\left(h^{2}\right)$ ranging from 0.25 to 0.5 (Murillo et al. 2013). Similar results have been reported in Asian breeding programs for growth traits (Goh and Monteuuis 2005, Goh et al. 2007, Goh and Monteuuis 2009; Chaix et al. 2011, Goh et al. 2013). Conversely, a 
strong genetic control was reported for wood traits, such as specific gravity, early heartwood formation, and heartwood color (Moya et al. 2013).

Understanding how genotype by environment interactions (GxE) affect genetic gain has been the goal of forest tree improvement organizations for a long time (Murillo 2001). For such organizations, a key decision is whether to keep one or several separated breeding programs, especially in a country with large environmental variation among regions. However, in order to be productive a balance must be achieved between genetic gain maximization and genetic diversity or kinship within breeding population (León et al. 2017). Several approaches have been proposed to monitor loss of genetic diversity in breeding programs (Vencovsky and Barriga 1992; Lindgren, Gea, and Jefferson 1996, 1997); those approaches can contribute to the optimal deployment of genetic material. Therefore, the objective of this study was to determine the best selection strategy for breeding Tectona grandis in the northern Pacific region of Costa Rica, i.e. the approach that maximizes genetic gain but reduces the risk of inbreeding.

\section{Materials and Methods}

\section{Source genetic material}

The Centro Agrícola Cantonal de Hojancha, a local NGO, selected the top 45 trees in plantations throughout the Guanacaste province (Northern Pacific of Costa Rica). Trees were selected based on phenotypic traits, only trees older than 5 years were considered. From this collection, half-sib seedlings from 28 families (plus trees) were own in nursery conditions and then transfer to the field to establish genetic trials. A control seed lot was included in all test sites. The control seed lot was a mix of regular commercial seeds from Hojancha's Seed Bank (the best local commercial seed available in the region).

\section{Progeny trials}

Progeny trials were established at four sites in the Northern Pacific region of Costa Rica (Table 1). All standard silvicultural treatments for teak were followed, that is, planted at $3 \times 3$ meters spacing, manual weed control with three to four interventions during the first two years, and fertilization only at planting time ( $50 \mathrm{~g} /$ plant of $10 \% \mathrm{~N}, 30 \% \mathrm{P}$, and $10 \% \mathrm{~K}$ ).

Table 1

Tectona grandis open-pollinated progeny trials in the Northern Pacific region of Costa Rica.

\begin{tabular}{|c|c|c|c|c|}
\hline $\begin{array}{l}\text { Test location } \\
\text { conditions }\end{array}$ & $\begin{array}{l}\text { Site 1: } \\
\text { Hojancha }\end{array}$ & $\begin{array}{l}\text { Site 2: } \\
\text { Jicaral }\end{array}$ & $\begin{array}{l}\text { Site 3: } \\
\text { Santa Cruz }\end{array}$ & $\begin{array}{l}\text { Site 4: } \\
\text { San Mateo }\end{array}$ \\
\hline Altitude (m) & 120 & 20 & 50 & 200 \\
\hline Dry months/year & 5 to 6 & 4 to 6 & 6 & 5 to 6 \\
\hline Rainfall (mm/year) & 2200 & 2500 & 2400 & 2200 \\
\hline $\begin{array}{l}\text { Soil and topog- } \\
\text { raphy }\end{array}$ & $\begin{array}{l}5 \text { to } 20 \% \\
\text { slope }\end{array}$ & $5 \%$ slope & $\begin{array}{l}2 \% \text { slope, poor } \\
\text { drainage }\end{array}$ & $5 \%$ slope \\
\hline Soil order & Alfisol & Alfisol & Vertisol & Alfisol \\
\hline $\begin{array}{l}\text { Land usage } \\
\text { before planting }\end{array}$ & Pasture & $\begin{array}{l}\text { Rice and } \\
\text { maize crops }\end{array}$ & Pasture & Fruit trees \\
\hline
\end{tabular}

\section{Experimental Design}

Trails were planted following GENFORES's experimental design, a randomized complete block design (RCB) with six blocks per test site. Each block is comprised of six progenies per family, arranged in three non-contiguous pairs and randomly distributed within the block. Families within blocks were the experimental unit (parcel). Therefore, 36 seedlings (progenies) represented each family at each test location. After 30 days, the trails were replanted to account for seedling mortality. All tests sites were thinned (50\%) at year four, removing the least adapted tree within each pair. Tree diameter $(\mathrm{dbh}$ in $\mathrm{cm}$ ) at the end of the seventh growing season was used for all analyses.

\section{Individual site analysis}

Data from each test site was analyzed separately using model 1 from SELEGEN REML/BLUP software version 2008 (Resende, 2016). The statistical model was $y=X r+Z a+W p+e$.

Where:

" $y$ " is a data vector,

" $r$ " is a vector of repetition effects (assumed as fixed) and added to the general mean;

"a" is a vector of individual additive genetic effects (assumed as random),

" $p$ " is a vector of plot effects assumed as random,

" $\mathrm{e}$ " is a vector of residuals (random).

Capital letters represent incidence matrices for the mentioned effects.

\section{Joint sites analysis}

Test sites data was first analyzed with pairwise comparisons and then in a single model with all test sites together, using statistical model 4 from SELEGEN REML/BLUP software version2008 (Resende, 2016). The statistical model across sites was $\mathrm{y}=\mathrm{Xr}+\mathrm{Za}+\mathrm{Wp}+\mathrm{Ti}+\mathrm{e}$.

Where:

" $y$ " is a data vector,

" $r$ " is a vector of repetition effects (assumed as fixed) and added to general mean. It includes all repetitions across locations (adjusts replication by site combinations and considers repetition within locations),

"a" is a vector of individual additive genetic effects (assumed as random),

" $p$ " is a vector of plot effects (assumed as random),

" $\mathrm{i}$ " is a vector of G X E interaction (assumed as random),

" $\mathrm{e}$ " is a vector of residuals (random).

Capital letters represent incidence matrices for the mentioned effects.

\section{Genetic parameters}

The following genetic parameters were estimated from the models:

$\mathrm{Vp}=\mathrm{Vad}+\mathrm{Vparc}+\mathrm{Ve}$ : phenotypical individual variance.

$h^{2} \mathrm{a}=\mathrm{Vad} / \mathrm{Vp}$ : individual heritability.

$c^{2}$ plot $=$ Vplot $/ \mathrm{Vp}$ : coefficient of determination for plot effect (block $x$ fam). It accounts for variances among plots within blocks. 
$\mathrm{h}^{2} \mathrm{mFam}=(0.25 \mathrm{Vad}) /[0.25 \mathrm{Vad}+$ Vplot $/ 6+(0.75 \mathrm{Vad}+\mathrm{Ve}) / 18]:$ mean family heritability. It assumes complete survival, 6 is the number of replications $(r=6), 3$ is the number of trees within each plot after thinning $(n=3)$, then 18 is the total number of effective trees in test.

Accuracy $=\sqrt[2]{h^{2} m F a m}$ : accuracy of family selection assuming complete survival.

$\mathrm{h}^{2} \mathrm{ad}=(0.75 \mathrm{Va}) /(0.75 \mathrm{Va}+\mathrm{Ve})$ : additive within family heritability.

CVgi $\%=[\sqrt[2]{\operatorname{Vad}} / \text { General mean }]^{*} 100$ : individual additive genetic variation coefficient.

CVgFam \%: $[\sqrt[2]{\operatorname{Vad} / 4} / \text { General mean }]^{*} 100:$ genotypic variation coefficient among families.

CVe $\%=\left\{\left[\sqrt[2]{\left[\frac{0.75 * V a d+V e}{3}+\text { Vplot }\right]}\right]\right) /$ General mean $\} * 100:$ experimental variation coefficient.

$\mathrm{CVr}=\mathrm{CVgFam} / \mathrm{CVe}=$ relative variation coefficient.

$\mathrm{PEV}=\left(1-\mathrm{Acc}\right.$ Prog $\left.^{2}\right)$ Va: prediction error variance of family genotypic values, assuming complete survival.

$\mathrm{SEP}=$ square root of PEV: standard deviation of genotypic family prediction values.

The parameters across sites were obtained as follows:

Vint: variance component for $\mathrm{G} \times \mathrm{E}$ interaction.

$c^{2}$ int $=$ Vint / Vf: determination coefficient for $G \times E$ interaction effects.

$\mathrm{h}^{2} \mathrm{ad}=(0.75 \mathrm{Va}) /(0.75 \mathrm{Va}+\mathrm{Ve})$ : additive heritability within plots.

rg-loc = Va / (Va + 4Vint): genotypic correlation for progeny performance across sites.

Effective population size was determined using Vencovsky and Barriga function (in Resende, 2002, page 70): $\mathrm{Ne}=\frac{\mathbf{4} * \mathbf{N}_{\mathbf{f}} * \mathbf{k}_{\mathrm{f}}}{\mathbf{K}_{\mathrm{f}}+\mathbf{3}}$ Where $\mathrm{Nf}$ is the number of families selected, while $\mathrm{kf}$ is the average number of " $k$ " individuals selected within the " $f$ " families. $\mathrm{Ne}$ increased with each new individual included in the selection, if the tree belongs to a new family. In order to maintain the highest possible $\mathrm{Ne}$, only the best two trees per family were selected.

For visualization of GxE complexity a graphical approach was performed, subdividing the ranking in three thirds. Based on the variation in family genetic value at each single test site, the ranking was splitted into three groups: high, middle and low diameter growth. The grouping division was established by: (highest - lowest value)/3, as suggested by Resende, Murillo and Badilla (2018). Therefore, test site variation was accounted for by its own data analysis. In this graphical representation, changes in the ranking among sites can be better observed. If changes in family ranking between two locations occur within the same grouping, GxE can be considered as insignificant. If changes in ranking are observed from the highest to the middle grouping, or from the lowest to the middle grouping, GxE interaction can be considered as significant but low and simple in nature.

\section{Results}

Table 2 shows the estimated genetic parameters for diameter, calculated by the SELEGEN software, for each test location. High genetic variation was found at the first three sites (Table 2 ), as shown by the individual genetic variation coefficient (CVgi \%). Values ranged from $9 \%$ to almost $11 \%$, which is considered high. Conversely, site 4 registered the lowest genetic variation, as well as an individual heritability below $10 \%$. The relative variation coefficient $(\mathrm{CVr})$ in the first three sites showed values over 0.48 , which reflects large genetic variation in the population for this trait. Meanwhile, family mean heritabilities were also high (ranging from $58 \%$ to $66 \%$ ) and supported by an accuracy value over $77 \%$. In terms of growth, sites 1, 2, and 4 showed similar rates at this age. However, site 3 exhibited the lowest value of all $(11.7 \mathrm{~cm}$ on average vs. values over $16.5 \mathrm{~cm}$ in other sites). Within family heritabilities ( $h^{2} \mathrm{ad}$ ) showed similar magnitudes and patterns to individual heritabilities $\left(h^{2} a\right)$ at all sites. Plot effect determination coefficients ( $c^{2}$ parc) registered low values in all sites, which reflects an optimal experimental design explained by absence of environmental heterogeneity.

Table 2

Genetic parameter estimates for diameter (dbh) in 7-year-old open-pollinated teak progeny trials at four locations in the Northern Pacific region of Costa Rica.

\begin{tabular}{lrrrr} 
Parameter & $\begin{array}{r}\text { Hojancha } \\
\text { (site 1) }\end{array}$ & $\begin{array}{r}\text { Jicaral } \\
(\text { site } 2)\end{array}$ & $\begin{array}{r}\text { Santa Cruz } \\
\text { (Site 3) }\end{array}$ & $\begin{array}{r}\text { San Mateo } \\
\text { (Site 4) }\end{array}$ \\
\hline Vad & 2.219 & 3.516 & 1.515 & 0.489 \\
Vplot & 0.033 & 0.395 & 0.130 & 0.052 \\
Ve & 3.398 & 7.329 & 2.357 & 5.595 \\
Vp & 5.650 & 11.240 & 4.002 & 6.136 \\
h$^{2} a$ & 0.393 & 0.313 & 0.379 & 0.080 \\
c $^{2}$ plot & 0.006 & 0.035 & 0.032 & 0.008 \\
h $^{2}$ mFam & 0.659 & 0.586 & 0.637 & 0.265 \\
Accuracy & 0.812 & 0.766 & 0.798 & 0.514 \\
$h^{2}$ ad & 0.329 & 0.265 & 0.325 & 0.062 \\
CVgi\% & 8.936 & 10.856 & 10.506 & 4.243 \\
CVgFam\% & 4.468 & 5.428 & 5.253 & 2.122 \\
CVe\% & 7.868 & 11.163 & 9.709 & 8.662 \\
CVr & 0.568 & 0.486 & 0.541 & 0.245 \\
PEV & 0.007 & 0.063 & 0.021 & 0.010 \\
SEP & 0.084 & 0.251 & 0.145 & 0.099 \\
Mean & 16.671 & 17.272 & 11.716 & 16.486 \\
\hline & & & &
\end{tabular}

Parameters in table 2 are defined as follows: Vad: additive genetic variance; Vplot: environmental variance among plots (Block x Family); Ve: residual variance (environmental but nonadditive).

Table 3 shows genetic parameters for diameter (dbh) in all possible pairwise site comparisons. Most of the pairwise combinations with site 3 (Santa Cruz) produced lower genetic parameters. Conversely, all pairwise combinations with site 1 (Hojancha) exhibited the highest values. 
Table 3

Genetic parameter estimates, among sites, for diameter (dbh) in a 7-year-old open-pollinated teak progeny trials at four locations in the Northern Pacific of Costa Rica.

\begin{tabular}{llllllll} 
Para- & Sites & Sites & Sites & Sites & Sites & Sites & Sites \\
meters & $1-3$ & $1-2$ & $1-4$ & $2-3$ & $3-4$ & $2-4$ & $1-2-3-4$ \\
\hline Vad & 1.613 & 2.192 & 1.897 & 1.289 & 0.604 & 1.760 & 1.594 \\
Vplot & 0.070 & 0.174 & 0.066 & 0.252 & 0.177 & 0.307 & 0.159 \\
Vint $_{\text {GxE }}$ & 0.057 & 0.191 & 0.011 & 0.310 & 0.238 & 0.212 & 0.181 \\
Ve & 2.888 & 6.289 & 5.203 & 5.411 & 4.682 & 8.033 & 5.294 \\
Vp & 4.628 & 8.846 & 7.178 & 7.263 & 5.702 & 10.312 & 7.229 \\
h$^{2} a$ & 0.348 & 0.248 & 0.264 & 0.178 & 0.106 & 0.171 & 0.221 \\
$c^{2}$ plot & 0.015 & 0.012 & 0.009 & 0.035 & 0.031 & 0.030 & 0.022 \\
$c^{2}$ int & 0.012 & 0.022 & 0.002 & 0.043 & 0.042 & 0.020 & 0.025 \\
hmFam $^{2}$ & 0.731 & 0.624 & 0.708 & 0.477 & 0.351 & 0.528 & 0.737 \\
Acc Prog & 0.855 & 0.790 & 0.842 & 0.691 & 0.593 & 0.727 & 0.858 \\
$h^{2}$ ad & 0.295 & 0.207 & 0.215 & 0.152 & 0.088 & 0.141 & 0.184 \\
rg-loc & 0.876 & 0.742 & 0.976 & 0.509 & 0.388 & 0.675 & 0.687 \\
PEV & 0.108 & 0.206 & 0.138 & 0.169 & 0.098 & 0.208 & 0.046 \\
SEP & 0.330 & 0.454 & 0.372 & 0.411 & 0.313 & 0.456 & 0.215 \\
Mean & 14.193 & 16.966 & 17.890 & 14.494 & 15.428 & 18.194 & 16.189 \\
\hline & & & & & & &
\end{tabular}

The deviance analysis (ANODEV) shows the goodness-of-fit of the model, statistical significance of additive genetic effects, and family by environment interactions across all four sites (Table 4). There were large significant variations among families and significative GxE interactions. In congruence, there were a significant variance component for the additive genetic effects, as well as for the GxE interactions.

Table 4

Analysis of deviance (ANODEV) for diameter (dbh) in four open-pollinated teak progeny tests, at different locations in the Northern Pacific of Costa Rica

\begin{tabular}{lllll} 
Effect & Deviance & (Chi-square) & Variance Comp. & $\begin{array}{l}\text { Determination } \\
\text { coefficient }\end{array}$ \\
\hline Family & 7701.07 & $23.46^{* *}$ & Vad $=0,3986^{* *}$ & $\mathrm{~h}^{2} \mathrm{a}=0.0552^{* *}$ \\
Plot & 7679.80 & $2.19^{\text {ns }}$ & Vplot $=0.1592^{\text {ns }}$ & $\begin{array}{l}\mathrm{c}^{2} \mathrm{plot}= \\
\end{array}$ \\
& & & & $0.0220^{\text {ns }}$ \\
Family X Loc & 7685.98 & $8.37^{* *}$ & Vint GxE $=0.1813^{* *}$ & $\mathrm{c}^{2}$ int $=0.0251^{* *}$ \\
Residual (error) & - & - & Ve $=5.2938$ & $\mathrm{c}^{2} \mathrm{res}=0.7323$ \\
Full model & 7677.61 & - & - & $\mathrm{c}^{2}$ total $=1.00$ \\
\hline
\end{tabular}

Chi- square values of 3.84 and 6.63 indicate the threshold for significance at $5 \%$ and $1 \%$, respectively, ${ }^{* *}$ indicates significant results, ns indicates non-significant results.

Figure 1 is a graphical representation of GxE interactions, it provides an easier visualization of GxE complexity. Most changes observed in family ranking across sites, occurred within the first grouping. A few of them moved from the top grouping to the middle one. Results for the lowest ranked families were consistent, either when analyzed independently per test site or when compared across all test locations. There was one exception, family 3 at Jicaral. This family ranked in the lowest grouping when looking only at that test site, but ranked in the top grouping when compared across all test locations. This result points to an unstable family under strong GXE interaction, complex in nature. Interesting to notice that Hojancha site is the one that best resembles the ranking of all sites.

\begin{tabular}{|c|c|c|c|c|c|c|c|c|c|}
\hline Fam & All Sites & Fam & San Mateo & Fam & Santa Cruz & Fam & Hojancha & Fam & Jicaral \\
\hline 4 & 20.14 & 5 & 21.37 & 15 & 17.45 & 5 & 21.41 & 4 & 22.02 \\
\hline 15 & 19.89 & 10 & 21.35 & 3 & 17.13 & 16 & 21.38 & 9 & 20.88 \\
\hline 10 & 19.63 & 15 & 21.29 & 4 & 16.49 & 13 & 21.31 & 10 & 20.66 \\
\hline 13 & 19.54 & 19 & 21.19 & 19 & 16.37 & 6 & 21.27 & 2 & 20.59 \\
\hline 3 & 19.48 & 14 & 20.94 & 28 & 16.37 & 3 & 21.22 & 7 & 20.57 \\
\hline 7 & 19.47 & 13 & 20.89 & 20 & 16.37 & 15 & 21.19 & 13 & 20.49 \\
\hline 19 & 19.46 & 21 & 20.87 & 50 & 16.35 & 8 & 21.19 & 21 & 20.14 \\
\hline 14 & 19.45 & 4 & 20.85 & 8 & 16.33 & 4 & 21.15 & 20 & 20.04 \\
\hline 21 & 19.43 & 3 & 20.73 & 27 & 16.31 & 10 & 21.01 & 14 & 20.02 \\
\hline 9 & 19.40 & 7 & 20.62 & 21 & 16.29 & 14 & 21.00 & 12 & 20.01 \\
\hline 5 & 19.33 & 33 & 20.36 & 25 & 16.23 & 7 & 20.99 & 27 & 19.95 \\
\hline 8 & 19.23 & 9 & 20.33 & 23 & 16.21 & 19 & 20.95 & 23 & 19.83 \\
\hline 20 & 19.19 & 23 & 20.33 & 14 & 16.16 & 28 & 20.88 & 8 & 19.80 \\
\hline 6 & 19.13 & 28 & 20.33 & 12 & 16.10 & 20 & 20.84 & 5 & 19.78 \\
\hline 25 & 19.10 & 25 & 20.32 & 29 & 16.07 & 25 & 20.77 & 6 & 19.77 \\
\hline 28 & 19.04 & 8 & 20.25 & 7 & 16.05 & 9 & 20.75 & 15 & 19.70 \\
\hline 23 & 19.02 & 6 & 20.19 & 33 & 16.04 & 21 & 20.73 & 19 & 19.66 \\
\hline 33 & 18.96 & 20 & 20.03 & 6 & 15.97 & 24 & 20.53 & 25 & 19.66 \\
\hline 12 & 18.84 & 2 & 19.98 & 24 & 15.91 & 33 & 20.30 & 33 & 19.56 \\
\hline 27 & 18.71 & 1 & 19.90 & 13 & 15.86 & 22 & 20.28 & 1 & 19.56 \\
\hline 2 & 18.63 & 24 & 19.81 & 9 & 15.84 & 29 & 20.27 & 3 & 19.36 \\
\hline 24 & 18.58 & 11 & 19.73 & 10 & 15.69 & 50 & 20.26 & 28 & 19.25 \\
\hline 1 & 18.48 & 12 & 19.71 & 22 & 15.61 & 23 & 20.16 & 35 & 19.15 \\
\hline 29 & 18.41 & 35 & 19.50 & 1 & 15.41 & 12 & 19.98 & 24 & 18.97 \\
\hline 50 & 18.24 & 29 & 19.47 & 5 & 15.39 & 27 & 19.73 & 29 & 18.79 \\
\hline 35 & 18.04 & 22 & 19.43 & 2 & 14.82 & 1 & 19.72 & 11 & 18.67 \\
\hline 16 & 18.03 & 50 & 19.43 & 35 & 14.79 & 35 & 19.70 & 16 & 18.26 \\
\hline 22 & 17.98 & 27 & 19.40 & 16 & 14.72 & 11 & 19.55 & 22 & 18.10 \\
\hline 11 & 17.90 & & & 11 & 14.70 & 2 & 19.43 & 50 & 18.07 \\
\hline
\end{tabular}

Figure 1

Graphical representation of GxE interaction complexity among four locations of teak progeny trials along the Northern Pacific of Costa Rica. Ranking was subdivided by three thirds at each location, based on genetic variation per progeny trial.

Selection strategy

The objective of this study was to determine the best selection strategy for breeding Tectona grandis in the Northern Pacific region of Costa Rica. Therefore, a genetic ranking of the top 20 single teak trees was constructed based on the combined analysis from all sites, under two criteria: no selection restriction and a maximum of two trees per family (Table 5). 
Table 5

Genetic ranking of the top 20 single teak trees based on its additive genetic values $(u+a)$ for diameter, under no selection restriction (left side) and, restricted to the best two trees per family (right side). Diameter genetic gain (GG) is given in cm.

\begin{tabular}{|c|c|c|c|c|c|c|c|c|}
\hline Ranking & Family & $\mathrm{u}+\mathrm{a}$ & GG & $\mathrm{Ne}$ & Family & $\mathrm{u}+\mathrm{a}$ & GG & $\mathrm{Ne}$ \\
\hline 1 & 13 & 19.2 & 3.01 & 1.00 & 13 & 19.2 & 3.01 & 1.00 \\
\hline 2 & 10 & 18.6 & 2.71 & 2.00 & 10 & 18.6 & 2.71 & 2.00 \\
\hline 3 & 13 & 18.5 & 2.56 & 2.48 & 13 & 18.5 & 2.56 & 2.48 \\
\hline 4 & 4 & 18.3 & 2.45 & 3.49 & 4 & 18.3 & 2.45 & 3.49 \\
\hline 5 & 4 & 18.2 & 2.35 & 4.11 & 4 & 18.2 & 2.35 & 4.11 \\
\hline 6 & 10 & 18.1 & 2.28 & 4.80 & 10 & 18.1 & 2.28 & 4.8 \\
\hline 7 & 7 & 18.0 & 2.22 & 5.72 & 7 & 18.0 & 2.22 & 5.72 \\
\hline 8 & 20 & 18.0 & 2.17 & 6.68 & 20 & 18.0 & 2.17 & 6.68 \\
\hline 9 & 13 & 18.0 & 2.12 & 6.94 & 3 & 18.0 & 2.12 & 7.66 \\
\hline 10 & 3 & 18.0 & 2.09 & 7.89 & 15 & 17.9 & 2.08 & 8.64 \\
\hline 11 & 10 & 17.9 & 2.06 & 8.21 & 8 & 17.8 & 2.03 & 9.63 \\
\hline 12 & 4 & 17.9 & 2.03 & 8.57 & 3 & 17.8 & 2.00 & 10.20 \\
\hline 13 & 13 & 17.9 & 2.00 & 8.69 & 5 & 17.7 & 1.96 & 11.20 \\
\hline 14 & 4 & 17.9 & 1.98 & 8.88 & 7 & 17.7 & 1.93 & 11.80 \\
\hline 15 & 15 & 17.9 & 1.96 & 9.77 & 9 & 17.7 & 1.90 & 12.80 \\
\hline 16 & 4 & 17.8 & 1.94 & 9.76 & 19 & 17.6 & 1.87 & 13.80 \\
\hline 17 & 8 & 17.8 & 1.92 & 10.60 & 21 & 17.6 & 1.85 & 14.80 \\
\hline 18 & 13 & 17.8 & 1.90 & 10.70 & 21 & 17.6 & 1.82 & 15.40 \\
\hline 19 & 3 & 17.8 & 1.88 & 11.40 & 9 & 17.6 & 1.80 & 16.00 \\
\hline 20 & 4 & 17.8 & 1.87 & 11.30 & 14 & 17.6 & 1.78 & 17.00 \\
\hline
\end{tabular}

Under no restriction to the number of trees per family the expected genetic gain was $1,87 \mathrm{~cm}(11,55 \%)$, meanwhile with a maximum of two trees per family the expected genetic gain dropped to $1,78 \mathrm{~cm}(11 \%)$. However, the main difference was in the effective population size or diversity $(\mathrm{Ne})$, which increased from 11.3 to 17 if restrictions were applied. Thus, the number of related individuals will be reduced. Conversely, the number of families represented will increase from 8 to 13 . Under this selection condition, the coefficient of inbreeding for the seeds produced in the seed orchard will drop from $F=4.5 \%$ to $2.9 \%$.

\section{DISCUSSION}

Both high genetic variability and low experimental coefficient of variation (CVe \%), resulted in higher values of individual heritability. In this study, individual heritabilities ranged from 8 to $39 \%$. These values revealed a high and a positive selection potential for breeding teak in Costa Rica. Furthermore, accuracy of selection showed values above $70 \%$ in all test sites, which are desirable and considered as very high (Resende 2016).

High genetic variation was found for the diameter trait in the joint analysis (Table 3). Individual heritabilities registered moderate to high magnitudes in all pairwise comparisons, except for site 3 with 4 ( $h^{2}$, below $\left.10 \%\right)$. Meanwhile, the four sites joint analysis registered an individual heritability value $\left(\mathrm{h}^{2}\right)$ of $22 \%$, which is high and favorable for selection. The results suggest that there can be a single breeding population for the whole Northern Pacific region of Costa Rica. This conclusion is supported by the genotype $x$ environment analysis. The determination coefficients for GxE interactions (c2int) revealed that the interactions among sites explained only a small proportion of the total phenotypic variability for all pairwise comparisons, except for combinations 2-3 and 3-4. For pairwise comparison 2-3 and 3-4 c2int values explained above $4 \%$ of the total variation. All genotypic correlations across sites were high, except for the combinations of site 3 with sites 2 and 4 . Site 3 is the least productive and exhibits stronger GxE effects than the other three sites. However, the genetic correlation involving the four sites combined was high in magnitude, indicating that the interaction is not problematic for breeding purposes since conceptually it is not complex in nature (Vencovsky \& Barriga 1992). In addition, site 1 (Hojancha) shows high correlations with all other sites, including site 3 . This suggests that Hojancha site could be chosen as a seed source suitable for most planting sites across the Northern Pacific region of Costa Rica.

Moreover, genetic effects and GxE interaction were significant, but not the plot effects (Table 4). However, since the genetic correlation across sites was high and strong, there is evidence that the GxE interaction, although significant, is simple in nature. That is, the genetic variability across environments is mainly explained by small differences in ranking positions or due to changes in the genotype response to different environments. Furthermore, the top ranking families $(4,13,14$, 15,21 , and 9) were always among the best at each site. Figure 1 supports this interpretation. There can be seen that small changes in ranking positions occurs when comparing any single site vs the joint analysis. These results agree with the high genotypic correlation between sites, observed in the joint analysis (r-gloc in table 3).

By establishing a seed orchard with the top 20 individuals, a genetic gain of $1.87 \mathrm{~cm}$ in diameter over the current general average $(16.19 \mathrm{~cm})$ would be expected. These 20 selected individuals correspond to an effective population size ( $\mathrm{Ne}$, unrelated individuals) of 11.27 , smaller than the actual population size (20) because of the kinship among several of these individuals (half-sibs). When a restriction is imposed on the number of individuals selected per family the expected genetic gain drops to $1.78 \mathrm{~cm}(11 \%)$, but the effective population size $(\mathrm{Ne})$ increases from 11.27 to 17 , an increment of $54.5 \%$. Under this selection conditions, the coefficient of inbreeding ( $F=1 / 2 \mathrm{Ne}$ ) for the seeds produced in the seed orchard will drop from $4.5 \%$ to $2.9 \%$. In this case, the value is estimated assuming complete 
allelic dominance (d) in a population under intermediate breeding progress. If the status number approach (Ns, Lindgren et al. 1996, 1997) is utilized, the coancestry value will be of 0.021 (close to $F=2.9 \%$ ) and the status number of 17.02 , which is almost the same value of $\mathrm{Ne}=16.97$ estimated with SELEGEN.

\section{Conclusions}

There were high individual heritability values for diameter at all sites combined, which indicates a potential for selection and genetic improvement in the teak population.

The observed GxE interaction was simple in nature and supported the development of a teak breeding program from a single seed source, suitable for the whole Northern Pacific of Costa Rica.

A genetic gain of over $11 \%$ in diameter growth is expected if the top 20 progenitors are selected, but only if restricted to a maximum of two trees per family.

\section{References}

Badilla Y, Xavier A, Murillo O (2016) Resgate vegetativo de árvores de Tectona grandis Linn F. pelo enraizamento de estacas. Revista Nativa (Brasil) vol 4 (2): 91-96. https://doi.org/10.14583/2318-7670.v04n02a07

Boshier D, Mesén F (1987) Proyecto de mejoramiento genético de árboles deL CATIE. Estado de avance y principales resultados. Turrialba. Costa Rica.

Chaix G, Monteuuis O, Garcia C, Alloysius D, Gidiman J, Bacilieri R, Goh DKS (2011) Genetic variation in major phenotypic traits among diverse genetic origins of teak (Tectona grandis L.f.) planted in Taliwas, Sabah, East Malaysia. Annals of Forest Science 68(5):1015-1026. https://doi.org/10.1007/s13595-011-0109-8

Chalmers WS (1962) The breeding of pine (Pinus caribaea Mor.) and teak (Tectona grandis L.) in Trinidad: Some early observations. Eighth British Commonwealth Forestry Conference, East Africa. 10 p. Trinidad, Government Printing Office.

Correa E, Espitia M, Aramendiz H, Murillo O, Pastrana I (2013) Variabilidad genética en lotes de semilla de Tectona grandis L.f. colectados en Córdoba, Colombia. Revista UDCA, Actualidad \& Divulgación Científica vol 16 (2): 379389

Espitia M, Murillo O, Castillo C (2011) Ganancia genética esperada en teca (Tectona grandis L.) en Córdoba (Colombia). Colombia Forestal vol 14(1): 81-93 / enero-junio, 2011. https://doi.org/10.14483/udistrital.jour.colomb.for.2011.1.a07

Goh DKS, Monteuuis O (2005) Rationale for developing intensive teak clonal plantations, with special reference to Sabah. Bois et Forêts des Tropiques 285: 5-15.

Goh DKS, Chaix G, Bailleres H, Monteuuis O (2007) Mass production and quality control of teak clones for tropical plantations: The Yayasan Sabah Group and Forestry Department of Cirad Joint Project as a case study. Bois et Forêts des Tropiques 293: 65-77.

Goh DKS, Monteuuis O (2009) Status of the 'YSG BIOTECH' program of building teak genetic resources in Sabah. Bois et Forêts des Tropiques 301: 33-49.

Goh DKS, Japarudin Y, Alwi A, Lapammu M, Flori A, Monteuuis O (2013) Growth differences and genetic parameter estimates of 15 teak (Tectona grandis L.f.) genotypes of various ages clonally propagated by microcuttings and planted under humid tropical conditions. Silvae Genetica 62 (4-5): 196-206. https://doi.org/10.1515/sq-2013-0024
Gutiérrez B, Quintero P, Nieto V, Murillo O (2003) Estrategias Cooperativas para e Mejoramiento Genético y la Conservación de Recursos Forestales en Chile, Colombia y Costa Rica. Investigación Agraria: Sistemas y Recursos Forestales 12(3): $111-122$

Keogh RM (1979) El futuro de la teca en la América tropical. Unasylva, 31(126): 13-19.

Lindgren D, Gea L, Jefferson PA (1996) Loss of Genetic Diversity Monitored by Status Number. Silvae Genetica 45: 52-60.

Lindgren D, Gea L, Jefferson PA (1997) Status Number for measuring genetic diversity. Forest Genetics 4: 69-76.

León N, Murillo O, Badilla Y, Ávila C, Murillo R (2017) Expected genetic gain and genotype by environment interaction in almond (Dipteryx panamensis (Pittier) Rec. and Mell) in Costa Rica. Silvae Genetica (2017) 66, 9-13. https://doi.org/10.1515/sg-2017-0002

Moya R, Marín JD, Murillo O, Leandro L (2013) Wood physical properties, color decay resistance and stiffness in Tectona grandis clones with evidence of genetic control. Silvae Genetica 62(3):142-152. https://doi.org/10.1515/sg-2013-0019

Moya R, Solera J, Guerrero R (2013) Capítulo 12: Comercialización de la teca in Las plantaciones de teca en América Latina: Mitos y realidades, edited by De Camino, R. and J.P. Morales. Boletín Técnico 397. CATIE. Turrialba, Costa Rica. 226-244

Murillo O (2001) Genotype by environment interaction and genetic gain analysis on unbalanced data of Pinus oocarpa provenances. Agronomía Costarricense. 25(1): 21-32.

Murillo O, Badilla Y (2004) Breeding teak in Costa Rica, in IUFRO Meeting. Forest Genetics and Genomics. November, 1-5. Charleston, South Carolina, USA. www.ncsu.edu/feop/iufro_genetics2004/proceedings.pdf.

Murillo O, Wright J, Monteuuis O, Montenegro F (2013) Capítulo 6: Mejoramiento genético de la teca en América Latina, pp. 86-111 in Las plantaciones de teca en América Latina: Mitos y realidades, edited by De Camino, R. and J.P. Morales. Boletín Técnico 397. CATIE. Turrialba, Costa Rica.

Pandey D, Brown C (2000) La teca: una visión global. Unasylva (FAO). 51 (201): 3-13.

Resende de MDV (2002) Genética Biométrica e Estatística no Melhoramento de Plantas Perenes. EMBRAPA. Brasilia, Brasil. 975 p.

Resende de MDV (2016) Software Selegen-REML/BLUP: a useful tool for plant breeding. Crop Breeding and Applied Biotechnology - 16: 330-339. https://doi.org/10.1590/1984-70332016v16n4a49

Resende de MDV, Murillo O, Badilla Y (2018) Genética Cuantitativa y Selección en el Mejoramiento Forestal. Editorial Tecnológica de Costa Rica. Cartago, Costa Rica. 302 pp.

Schnell e Schuhli G, Paludzyszyn F (2010) O cenário da silvicultura de teca e perspectivas para o melhoramento genético. Pesquisa Florestal Brasileira (Colombo) 30(63): 217-230. https://doi.org/10.4336/2010.pfb.30.63.217

Vallejos J, Badilla Y, Picado F, Murillo O (2010) Metodología para la selección e incorporación de árboles plus en programas de mejoramiento genético forestal. Agronomía Costarricense 34:105-119.

Vencovsky R, Barriga P (1992) Genetica biometrica no fitomelhoramento. Ribeirao Preto: Sociedad Brasileira de Genetica. 